\title{
ANALISIS PENGARUH KONDISI KEUANGAN DAN UKURAN PERUSAHAAN TERHADAP BUSINESS RISK \\ (STUDI KASUS PADA PERUSAHAAN PERBANKAN YANG TERDAFTAR DI BURSA EFEK INDONESIA)
}

\author{
Hendro Adi Prasetyo \\ Triyono \\ Universitas Muhammadiyah Surakarta \\ e-mail: hendro_adiprasetyo@yahoo.com
}

\begin{abstract}
Bank is a firm which collects funds from society in the deposit term and spread it in the credit term and or in the other tems to increase the standard living of society. Therefore, it is urgent to get people's credibility, because the activities of the bank rely on that. The aim of this research is to analyse the financial condition effect in proxcy with capital adequacy ratio (CAR), non performing loan (NPL), loan to deposit ratio (LDR), net interest margin (NIM), and firm size toward business risk measured by deviation standart from return on asset (ROA). The methods of this research are double regression analisys, proper model test, classic assumptions test, and hypothesis test. The source of data used in this research are the banks in Indonesia Stock Exchange registered in 2008-2012. The data are chosen by using purposive sampling method which bank reports the annual report and Indonesian Capital Market Directory (ICMD) . From those criteria, this research gets 111 banks. The result shows that capital adequacy ratio (CAR), non performing loan (NPL), and net interest margin (NIM) have the significant influences toward business risk. While loan to deposit ratio (LDR) and firm size have no significant influences to business risk.
\end{abstract}

Key words: financial condition, firm size, and business risk

\section{PENDAHULUAN}

Setiap perusahaan mempunyai karakteristik tersendiri sehingga dalam pengelolaannya harus disesuaikan dengan karakteristik perusahaan yang bersangkutan. Salah satu karakteristik yang berbeda adalah antara perusahaan yang memasarkan produk yang berupa barang dengan perusahaan yang memasarkan produk yang berupa jasa. Kedua jenis perusahaan tersebut membutuhkan sistem pengelolaan yang berbeda, walaupun dalam beberapa hal terdapat kesamaan.
Salah satu perusahaan yang memasarkan produk yang berupa jasa adalah lembaga keuangan bank.

Peranan utama bank sebagai lembaga intermediasi keuangan (financial intermediary) adalah mengalihkan dana dari pihak yang kelebihan dana (surplus) kepada pihak yang kekurangan dana (deficit) disamping menyediakan jasa-jasa keuangan lainnya. Karena bank berfungsi sebagai lembaga intermediasi keuangan atau perantara keuangan, maka dalam hal ini faktor "kepercayaan" dari masyarakat atau nasabah merupakan faktor utama dalam menjalankan bisnis perbankan. Dengan demikian 
manajemen bank akan dihadapkan pada berbagai usaha untuk menjaga kepercayaan tersebut, agar tetap memperoleh simpati dari calon nasabahnya (Martono, 2004:19).

Menurut Undang-Undang RI Nomor 10 Tahun 1998 tanggal 10 November 1998 tentang perbankan, yang dimaksud dengan bank adalah badan usaha yang menghimpun dana dari masyarakat dalam bentuk simpanan dan menyalurkannya kepada masyarakat dalam bentuk kredit dan atau bentuk-bentuk lainnya dalam rangka meningkatkan taraf hidup rakyat banyak(Kasmir, 2009:25). Sementara itu, menurut F.E. Perry, bank adalah suatu badan usaha yang transaksinya berkaitan dengan uang, menerima simpanan (deposit) dari nasabah, menyediakan dana atas setiap penarikan, melakukan penagihan cek-cek atas perintah nasabah, memberikan kredit, dan atau menanamkan kelebihan simpanan tersebut sampai dibutuhkan untuk pembayaran kembali (Rivai, dkk. 2013: 1).

Risiko perbankan adalah risiko yang dialami oleh sektor bisnis perbankan sebagai bentuk dari berbagai keputusan yang dilakukan dalam berbagai bidang seperti keputusan penyaluran kredit, penerbitan kartu kredit, valuta asing, inkaso dan berbagai bentuk keputusan finansial lainnya, dimana itu telah menimbulkan kerugian bagi perbankan tersebut, dan kerugian terbesar adalah dalam bentuk finansial. Bank menyediakan fasilitas yang mampu memberikan kemudahan karena publik sebagai nasabahnya untuk memperlancar segala urusannya yang menyangkut dengan masalah keuangan.

Karena fungsinya sebagia mediasi, bank harus mampu menyediakan atau memberikan kemudahan itu, seperti keamanan simpanan, kemudahan dalam menarik kembali dana dalam jumlah yang disesuaikan, kemudahan dalam urusan mencairkan kredit termasuk rendahnya biaya administrasi yang ditanggung, suku bunga kredit yang rendah dan perhitungan yang dilakukan secara cepat dan akurat. Risiko yang dialami perbankan menjadi sesuatu yang kompleks pada saat bank tersebut terlibat dalam transaksi valuta asing (valas). Krisis nilai tukar yang melanda Asia pada tahun 1997 lalu telah banyak menyebabkan perbankan mengalami masalah khususnya perbankan swasta nasional (Fahmi, 2010:100).

Tujuan penelitian ini adalah untuk menganalisis dan memberikan bukti empiris tentang pengaruh kondisi keuangan yang di proxy dengan capital adequacy ratio (CAR), non performing loan (NPL), loan to deposit ratio (LDR) dan net interest margin (NIM) dan ukuran perusahaan terhadap business risk pada perusahaan perbankan yang terdaftar di Bursa Efek Indonesia. Dari hasil penelitian ini diharapkan dapat digunakan sebagai bahan pertimbangan bagi manajemen perbankan nasional dalam praktik manajemen risiko perbankan, terutama terkait dengan pengelolaan risiko bisnis bank sehingga dapat meningkatkan kinerja perbankan nasional, dan bagi nasabah dapat memberikan manfaat terkait sikap selektif yang perlu digunakan dalam memilih perbankan yang berkualitas dan terpecaya agar terhindar dari risiko perbankan.

\section{REVIEW LITERATUR DAN HIPOTESIS}

\section{Risiko Bisnis (Business Risk)}

Setiap bisnis menghadapi tantangan yang setara antara pertumbuhan pendapatan dan pengelolaan risiko, sebab setiap keputusan bisnis mengandung elemen risiko didalamnya. Seiring waktu, keputusan-keputusan bisnis dan risiko yang diambil secara kolektif tumbuh menjadi portofolio risiko perusahaan secara keseluruhan dengan profil risiko yang unik. Profil risiko ini akan mempengaruhi perusahaan. Pada dasarnya risiko tidak dapat dihindari dari aktivitas bisnis perusahaan, sehingga diperlukan manajemen risiko untuk mengatasi permasalahan ini (Hanggraeni,2010:1). 
Prasetyo menyatakan (2013) risiko bisnis bank pada dasarnya merupakan suatu ketidakpastian mengenai pendapatan (keuntungan) yang diperkirakan akan diterima. Ketidakpastian pada umumnya dapat diukur dengan menggunakan simpangan baku (standar deviasi). Sedangkan mengenai pendapatan (keuntungan), dalam beberapa penelitian umumnya diproksikan dengan menggunakan rasio keuangan return on asset (ROA). Sementara aset merupakan unsur yang mampu mewakili kepentingan nasabah mengingat aset bank sebagian besar bersumber dari dana simpanan masyarakat dalam bentuk dana pihak ketiga. Oleh karena itu, SDROA (Standard Deviation of Return on Asset) dipilih sebagai proksi dari risiko bisnis bank (variabel dependen) dalam penelitian ini. SDROA (Standard Deviation of Return on Asset) adalah tingkat deviasi standar dari return on asset (ROA). Pilihan yang berisiko memiliki range simpangan keuntungan atau kerugian yang lebih besar dan ukuran risiko yang lazim adalah simpangan baku (deviasi standar).

Berdasarkan PBI No.5/8/PBI/2003 tanggal 19 Mei 2003 jenis risiko perbankan antara lain yaitu: (1) risiko kredit, yaitu risiko akibat kegagalan pihak debitur dalam memenuhi kewajibannya. (2) risiko pasar, yaitu risiko yang timbul karena adanya pergerakan variabel pasar dari portofolio yang dimiliki bank. (3) risiko likuiditas, yaitu risiko yang disebabkan bank tidak mampu memenuhi kewajibannya yang telah jatuh tempo. (4) risiko operasional, yaitu risiko yang disebabkan ketidakcukupan dan tidak berfungsinya proses internal, kesalahan manusia, kegagalan manusia, kegagalan sistem, atau problem eksternal yang mengganggu operasional bank. (5) risiko reputasi, yaitu risiko yang berkaitan dengan kegiatan bank yang dinilai negatif dengan adanya publikasi. (6) risiko hukum, yaitu risiko yang disebabkan adanya tuntutan hukum, ketiadaan peraturan perundangundangan yang mendukung, kelemahan peri- katan. (7) risiko strategik, yaitu risiko yang timbul akibat pelaksanaan strategi bank dan pengambilan keputusan bisnis yang tidak tepat atau kurang responsif. (8) risiko kepatuhan, yaitu risiko yang timbul akibat bank tidak mematuhi atau tidak melaksanakan peraturan perundangundangan dan ketentuan yang berlaku, terutama peraturan yang dikeluarkan Bank Indonesia.

\section{Kondisi Keuangan}

\section{a. Capital Adequacy Ratio (CAR)}

Capital Adequasi Ratio (CAR) ialah salah satu rasio yang digunakan dalam pengukuran permodalan perbankan. Rasio CAR menunjukkan sejauh mana seluruh aktiva bank yang mengandung risiko (kredit, penyertaan, surat berharga, tagihan pada bank lain) ikut dibiayai dari dana modal sendiri disamping memperoleh dana dari sumber lain, seperti dana masyarakat, pinjaman atau hutang dan lain-lain (Kusumawati,2009).

\section{b. Non Performing Loan (NPL)}

Daelawati, et.al (2009) menyatakan NPL menunjukkan kemampuan sebuah bank dalam mengumpulkan kembali kredit yang dikeluarkan oleh bank hingga lunas. Apabila suatu bank mempunyai angka NPL yang tinggi, maka biaya operasi akan makin besar, baik biaya pencadangan aktiva produktif maupun biaya lainnya. Dengan kata lain semakin tinggi NPL suatu bank, maka kinerja bank akan semakin buruk.

\section{c. Loan to Deposit Ratio (LDR)}

Loan to deposit ratio (LDR) merupakan rasio yang mengukur kemampuan bank untuk memenuhi kewajiban yang harus dipenuhi. Sehingga semakin tinggi loan to deposit ratio (LDR) maka laba bank semakin meningkat (dengan asumsi bank tersebut mampu menyalurkan kreditnya dengan efektif), dengan meningkatnya laba bank, maka kinerja bank juga meningkat (Hutagalung,et.al, 2013). 


\section{d. Net Interest Margin (NIM)}

Prasetyo (2013) menyatakan net interest margin (NIM) digunakan untuk mengukur kemampuan manajemen bank dalam mengelola aktiva produktifnya untuk menghasilkan pendapatan bunga bersih. Pendapatan bunga bersih diperoleh dari pendapatan bunga dikurangi beban bunga. Rasio ini menunjukkan kemampuan bank dalam memperoleh pendapatan operasionalnya dari dana yang ditempatkan dalam bentuk pinjaman atau kredit.

\section{e. Ukuran Perusahaan}

Ukuran perusahaan adalah suatu skala dimana dapat diklasifikasikan besar kecilnya perusahaan menurut berbagai cara antara lain dengan total aktiva, penjualan bersih, dan kapitalisasi pasar perusahaan (market capitalization). Perusahaan yang memiliki total aktiva besar menunjukkan bahwa perusahaan tersebut telah mencapai tahap kedewasaan dimana dalam tahap ini arus kas perusahaan sudah positif dan dianggap memiliki prospek yang baik dalam jangka waktu yang relatif lama (Diantimala, 2008).

\section{Penelitian Terdahulu dan Pengembangan Hipotesis}

Penelitian yang dilakukan oleh Prasetyo (2013) pada bank umum swasta nasional devisa, yang menunjukkan bahwa capital adequacy ratio (CAR), non performing loan (NPL), loan to deposit ratio, dan net interest margin (NIM) secara simultan signifikan terhadap risiko bisnis (SDROA) dengan menggunakan metode penelitian analisis regresi. Tapi dari keempat variabel indepnden independen hanya variabel CAR, NPL, NIM dan secara parsial signifikan terhadap risiko bisnis (SDROA) bank devisa umum yang memasarkan sahamnya ke investor dan hanya variabel LDR yang tidak signifikan.

Penelitian yang dilakukan Soedarmono, et.al (2010) bertujuan untuk menginvestigasi hubungan antara kekuatan pasar pada perusahaan perbankan dan pengambilan risiko bank yang berada di Asia. Penelian ini menggunakan metode penelitian analisis regresi dan dalam penelitiannya menunjukkan bahwa return on equity (ROE) dan Capital adequacy ratio (CAR) negatif tidak signifikan terhadap SDROA, sementara itu non performing loan (NPL), overhead dan size negatif signifikan terhadap SDROA.

Penelitian yang dilakukan Kwan (2004) yang bertujuan untuk membandingkan risiko kredit, risiko pendapatan, kapitalisasi, dan kegagalan antara publicly traded dan non-publicly traded bank. Penelitian ini menggunakan metode penelitian dengan analisis regresi dan dalam penelitiannya menunjukkan bahwa Log TA negatif signifikan terhadap SDROA, sementara itu loan to deposit ratio (LDR) dan deposit/TA positif signifikan terhadap standar deviasi dari return on asset (SDROA).

Penelitian yang dilakukan oleh Goldlewski (2004) yang bertujuan untuk ukuran pendapatan dan risiko pada perusahaan perbankan pada bank-bank di Argentina, Bolivia, Columbia, Ekuador, Indonesia, Korea Selatan, Mexico, Peru, Thaliland, dan Venezuela, mengenai pengukuran risiko yang diukur dengan standar deviasi dari ROA dan ROE. Berdasarkan hasil penelitiannya menunjukkan bahwa non performing loan (NPL) berpengaruh positif signifikan terhadap SDROA, sedangkan variabel loan to deposit ratio (LDR) dan net interest margin (NIM) berpengaruh negatif terhadap SDROA.

\section{Pengaruh capital adequacy ratio (CAR) terhadap business risk}

Rahim dan Irpa (2008) menyatakan capital adequacy ratio (CAR) merupakan modal yang harus dipenuhi oleh bank. Modal ini digunakan untuk menjaga kepercayaan masyarakat terhadap kinerja bank. Hal ini wajar sebab bisnis perbankan adalah bisnis yang berdasarkan kepercayaan. Selain itu, adanya berbagai bentuk risiko yang 
besar yang mungkin dapat terjadi pada bank. Faktor utama yang cukup mempengaruhi jumlah modal bank adalah jumlah modal minimum yang ditentukan oleh penguasa moneter yang biasanya merupakan wewenang dari bank sentral. Sedangkan Prasetyo (2013) menyatakan semakin tinggi CAR maka semakin kuat kemampuan bank tersebut untuk menanggung risiko dari setiap kredit atau aktiva produktif yang berisiko. Dari pernyataan tersebut maka dapat dirumuskan hipotesis sebagai berikut:

$$
\begin{aligned}
\mathrm{H} 1= & \text { Capital adequacy ratio berpengaruh } \\
& \text { terhadap business risk. }
\end{aligned}
$$

\section{Pengaruh non performing loan (NPL) terhadap business risk}

Rahim dan Irpa (2008) menyatakan non performing loan (NPL) merupakan tingkat pengembalian kredit yang diberikan deposan kepada bank dengan kata lain NPL merupakan tingkat kredit macet pada bank tersebut. Apabila NPL rendah maka bank tersebut akan mengalami keuntungan, sebaliknya apabila NPL tinggi maka bank tersebut akan mengalami kerugian yang diakibatkan oleh tingkat pengembalian kredit macet. Ali (2004) dalam Prasetyo (2013) menyatakan semakin kecil NPL, semakin kecil risiko kredit yang ditanggung oleh bank. Dari pernyataan tersebut maka hipotesis yang diajukan adalah sebagai berikut:

$\mathrm{H} 2=$ Non performing loan berpengaruh terhadap business risk.

\section{Pengaruh loan to deposit ratio (LDR) terhadap business risk}

LDR mencerminkan kegiatan utama suatu bank yang dapat diartikan tingkat penyaluran kredit juga mempengaruhi besarnya nilai ROA, dimana rasio yang mengukur perbandingan jumlah kredit yang diberikan bank dengan dana yang diterima oleh bank (Defri, 2012). Jika bank menyalurkan seluruh dana yang dihimpun, maka akan sangat terkait dengan risiko. Hal ini dikarenakan apabila sewaktu-waktu pemilik dana menarik dananya atau pemakai dana tidak dapat mengembalikan dana yang dipinjamnya (Prasetyo, 2013). Dari pernyataan tersebut maka hipotesis yang diajukan adalah sebagai berikut:

$\mathrm{H} 3=$ Loan to deposit ratio berpengaruh terhadap business risk

\section{Pengaruh net interest margin (NIM) terhadap business risk}

Hutagalung et.al (2013) menjelaskan net interest margin (NIM) mencerminkan resiko pasar yang timbul karena adanya pergerakan variabel pasar, dimana hal tersebut dapat merugikan bank. Sedangkan Ariyanto (2011) menyatakan perbankan diasumsikan memiliki sikap risk averse. Dalam kondisi risk averse, makin tinggi resiko yang dihadapi oleh bank, maka kompensasi marjin terhadap risiko tersebut juga akan makin besar, begitu juga dengan kondisi sebaliknya. Dengan demikian, pengaruh persepsi risiko bank berdampak positif terhadap tingkat net interest margin. Dari pernyataan tersebut maka hipotesis yang diajukan adalah sebagai berikut:

$\mathrm{H} 4=$ Net interest margin berpengaruh terhadap business risk.

\section{Pengaruh ukuran perusahaan terhadap business risk}

Hartono (2010: 392) menyatakan variabel ukuran aktiva (asset size) diukur sebagai logaritma dari total aktiva. Variabel ini diprediksi mempunyai hubungan yang negatif dengan risiko. Ukuran aktiva dipakai sebagai proxy besarnya perusahaan. Perusahaan yang lebih besar dianggap mempunyai risiko yang lebih rendah dibandingkan dengan perusahaan yang lebih kecil. Sedangkan Hendrayanti dan Muharam (2013) menjelaskan ukuran perusahaan dapat mempengaruhi kemampuan bank dalam menghasilkan laba. Pada umumnya perusahaan besar yang memiliki total aktiva yang besar mampu menghasilakn laba yang besar. Perusahaan yang berukuran besar mempunyai daya tarik 
tersendiri bagi konsumen karena perusahaan besar yang cenderung memiliki risiko kebangkrutan yang lebih kecil karena jumlah asetnya cenderung besar. Dari pernyataan tersebut maka hiposis yang diajukan adalah sebagai berikut:

H5 = Ukuran perusahaan berpengaruh terhadap business risk.

\section{METODE PENELITIAN}

\section{Pemilihan Sampel dan Pengumpulan Data}

Populasi dalam penelitian ini adalah semua perusahaan perbankan yang terdaftar di Bursa Efek Indonesia. Dalam penelitian ini pemilihan sampel menggunakan purposive sampling, yaitu teknik penentuan sampel dengan pertimbangan tertentu (Sugiono, 2008:122). Adapun kriteria yang digunakan dalam memilih sampel adalah sebagai berikut:

1. Perusahaan yang bergerak pada dunia perbankan dan terdaftar sebagai perusahaan publik di Bursa Efek Indonesia selama tahun 2008-2012.

2. Mempublikasikan annual report dan laporan keuangan tahunan 31 Desember untuk tahun buku 2008-2012.

3. Laporan keuangan dinyatakan dalam bentuk rupiah.

\section{Definisi Operasional dan Pengukuran Variabel}

\section{Business risk (risiko bisnis)}

Brigham dan Houston (2001:45) dalam Sembiring (2012) menyatakan business risk (risiko bisnis) merupakan ketidakpastian mengenai proyeksi pengembalian atas aktiva di masa mendatang. Perusahaan yang mempunyai pendapatan yang lebih stabil mampu mempertahankan tingkat laba sehingga akan mampu memenuhi kewajibannya tanpa menanggung suatu risiko kegagalan. Sunaryo (2007:13) menyatakan ukuran yang lazim untuk mengukur tingkat risiko adalah simpangan baku atau standar deviasi $(\sigma)$. Dalam penelitian ini business risk diukur menggunakan standar deviasi dari return on asset (SDROA). Adapun menurut Rivai, dkk (2007: 720) return on asset (ROA) dihitung dengan rumus:

$$
\mathrm{ROA}=\frac{\text { Laba sebelum pajak }}{\text { Total Aktiva }} \times 100 \%
$$

\section{Capital Adequacy Ratio (CAR)}

Capital adequacy ratio (CAR) adalah rasio keuangan yang berkaitan dengan permodalan perbankan dimana besarnya modal suatu bank akan berpengaruh pada kemampuan atau tidaknya suatu bank secara efisien menjalankan kegiatannya (Hutagalung, et.al, 2011). Rivai,dkk. (2007:712) menyatakan capital adequacy ratio (CAR) dapat dihitung dengan rumus:

$$
\mathrm{CAR}=\frac{\text { Modal }}{\text { AMTR }} \times 100 \%
$$

\section{Non Performing Loan (NPL)}

Non performing loan (NPL) yaitu perbandingan antara kredit bermasalah terhadap total kredit. Rasio ini mengindikasikan bahwa semakin tinggi rasio NPL menunjukkan semakin buruk kualitas kreditnya (Taswan, 2010:166). Kusumawati (2009) menyatakan NPL dapat dihitung dengan rumus sebagai berikut:

$$
\mathrm{NPL}=\frac{\text { Kredit kurang lancar }+ \text { Kredit diragukan }+ \text { Kredit macet }}{\text { Total Kredit }} \text { X 100\% }
$$

\section{Loan To Deposit Ratio (LDR)}

Hutagalung, et.al. (2011) menyatakan loan to deposit ratio (LDR) merupakan rasio yang mengukur kemampuan bank untuk memenuhi kewajiban yang harus dipenuhi. Sedangkan Rivai,dkk. (2007:724) menyatakan loan to deposit ratio (LDR) dapat dihitung dengan rumus:

$\mathrm{LDR}=\frac{\text { Jumlah kredit yang diberikan }}{\text { Total dana pihak ketiga }} \times 100 \%$ 


\section{Net Interest Margin (NIM)}

Almalia dan Herdiningtyas (2005) menyatakan rasio NIM digunakan untuk mengukur kemampuan manajemen bank dalam mengelola aktiva produktifnya untuk menghasilkan pendapatan bunga bersih. Pendapatan bunga bersih diperoleh dari pendapatan bunga dikurangi beban bunga. Menurut Rivai, dkk (2007: 721) Net interest margin (NIM) dihitung dengan rumus:

$\mathrm{NIM}=\frac{\text { Pendapatan Bersih (Pendapatan Bunga-Beban Bunga) }}{\text { Aktiva Produktif }}$ X 100\%

\section{Size (ukuran perusahaan)}

Ukuran perusahaan merupakan ukuran atau besarnya aset yang dimiliki perusahaan. Size diproksikan dengan total aset kemudian total aset diubah menjadi logaritma natural dari total aset (Naucer, 2003 dalam Taunay 2009). Hal ini dikarenakan bahwa besarnya masing-masing total aset berbeda-beda antara masing-masing perusahaan, bahkan mempunyai selisih yang sangat besar sehingga dapat menyebabkan nilai ekstrim (Budiyanti dan Ifada,2012). Sehingga size (ukuran perusahaan) dapat dirumuskan sebagai berikut:

$$
S I Z E=\operatorname{Ln}(\text { total aset })
$$

\section{Model Regresi}

Pengujian ini digunakan untuk mengukur nilai Y dan seberapa pengaruh analisis kondisi keuangan yang diproksikan dengan capital adequacy ratio (CAR), non performing loan (NPL), loan to deposit ratio (LDR), net interest margin (NIM) dan ukuran perusahaan terhadap business risk (SDROA). Adapun model regresi penelitian dirumuskan sebagai berikut:

$$
\begin{gathered}
\text { RISK }_{(\text {SDROA) }}=\alpha+\beta_{1} \mathrm{CAR}+\beta_{2} \mathrm{NPL}+\beta_{3} \mathrm{LDR}+ \\
\beta_{4} \mathrm{NIM}+\beta_{5} \mathrm{SIZE}+\varepsilon \ldots \ldots .
\end{gathered}
$$

Keterangan:

RISK = Business Risk (standar deviasi ROA)

$\mathrm{CAR}=$ Capital adequacy ratio

$\mathrm{NPL}=$ Non performing loan

$$
\begin{aligned}
& \mathrm{LDR}=\text { Loan to deposit ratio } \\
& \mathrm{NIM}=\text { Net interest margin } \\
& \text { SIZE = Ukuran Perusahaan } \\
& \alpha=\text { Konstanta } \\
& \varepsilon=\text { Error Term } \\
& \beta_{1-5}=\text { Nilai Koefisien Variabel Dari Tiap - } \\
& \text { Tiap Variabel X }
\end{aligned}
$$

\section{HASIL PENELITIAN DAN PEMBAHASAN}

\section{Analisis Regresi Linier Berganda}

Adapun hasil analisis data dalam penelitian ini dimaksudkan untuk mengetahui pengaruh kondisi keuangan yang diproksikan dengan capital adequacy ratio (CAR), non performing loan (NPL), loan to deposit ratio (LDR), net interest margin (NIM) danukuran perusahaan terhadap business risk.

\section{Tabel 1}

\section{Hasil Uji Regresi Linier Berganda}

\begin{tabular}{ccccc}
\hline Variabel & $\begin{array}{c}\text { Koeffisien } \\
\text { Regresi }\end{array}$ & $\begin{array}{c}\mathrm{t}_{\text {hitung }} \\
\text { Konstanta }\end{array}$ Signifikan & Kesimpulan \\
CAR & 0.000 & -0.220 & 0.826 & - \\
NPL & 0.053 & 2.641 & 0.010 & Signifikan \\
LDR & 0.001 & 3.643 & 0.000 & Signifikan \\
NIM & 0.038 & 3.809 & 0.494 & Tidak Signifikan \\
SIZE & -0.006 & -0.493 & 0.000 & Signifikan \\
F & 8.586 & & 0.623 & Tidak Signifikan \\
$\mathrm{R}^{2}$ & 0.290 & & & \\
Adjusted R & 0.256 & & & \\
\hline
\end{tabular}

Sumber: Hasil olah data, 2013

Penjelasan dari regresi adalah sebagai berikut: Nilai konstanta sebesar 0.000 menunjukkan bahwa jika variabel CAR, NPL, LDR, NIM, dan Size diasumsikan konstan atau sama dengan nol maka besarnya risiko akan meningkat. Koefisien regresi variabel CAR bernilai positif sebesar 0.012. Hal ini menunjukkan bahwa apabila tingkat capital adequacy ratio tinggi maka risiko yang akan diambil perusahaan juga akan tinggi. Koefisien regresi variabel NPL bernilai positif sebesar 0.053. Hal ini menunjukkan bahwa apabila tingkat non performing loan tinggi maka risiko yang akan diambil perusahaan juga akan tinggi. Koefisien regresi variabel LDR bernilai positif 
sebesar 0.001. Hal ini menunjukkan bahwa apabila loan to deposit ratio tinggi maka risiko yang akan diambil perusahaan akan tinggi. Koefisien regresi variabel NIM bernilai positif sebesar 0.038. Hal ini menunjukkan bahwa apabila net interest margin tinggi maka risiko yang akan diambil perusahaan juga akan tinggi. Koefisien regresi variabel Size bernilai negatif sebesar -0.006. Hal ini menunjukkan bahwa semakin besar ukuran perusahaan maka risiko yang akan diambil perusahaan juga akan semakin rendah.

\section{Uji ketepatan model}

\section{Uji Signifikan Simultan (Uji F)}

Uji ini bertujuan untuk mengevaluasi pengaruh semua variabel independen terhadap variabel dependen secara bersama-sama. Berdasarkan hasil pengolahan data pada tabel 1, menunjukkan hasil nilai $\mathrm{F}_{\text {hitung }}$ (8.586) dengan nilai $p$-value $=0.000$ dengan ketentuan nilai probabilitas $<5 \%$, Jadi dapat disimpulkan bahwa variabel capital adequacy ratio (CAR), non performing loan (NPL), loan to deposit ratio (LDR), net interest margin (NIM), dan ukuran perusahaan (size), secara simultan mempunyai pengaruh yang signifikan terhadap business risk. Dari hasil tersebut juga dapat dijelaskan bahwa model goodness of fit.

\section{Uji Koefisien Determinasi $\left(\mathbf{R}^{2}\right)$}

Analisis ini bertujuan untuk mengukur besar kemampuan menerangkan dari variabel independen terhadap variabel dependen dalam satu model regresi. Berdasarkan hasil analisis data pada tabel 1 tersebut diperoleh nilai Adjusted $\mathrm{R}^{2}$ sebesar 0.256 yang berarti sebesar $25.6 \%$ variabel dependen yaitu business risk (SDROA) dapat dijelaskan oleh variabel independen yaitu capital adequacy ratio (CAR), non performing loan (NPL), loan to deposit ratio (LDR), net interest margin (NIM) dan size (ukuran perusahaan). Sedangkan, sisanya dijelaskan oleh faktor-faktor diluar model yang diteliti yaitu sebesar 74.4\%.

\section{Uji Asumsi Klasik}

Dari hasil pengujian asumsi klasik yang dipersyaratkan untuk model regresi diperoleh kesimpulan bahwa semua asumsi telah terpenuhi berdasarkan hasil berikut:

Berdasarkan hasil uji normalitas diperoleh nilai One Kolmogrov-Smirnov Z sebesar 1.028 dengan $p$-value sebesar 0.242 yang lebih besar dari $\alpha=0,05(0.242>0,05)$. Sehingga dapat diambil kesimpulan bahwa residual model regresi terdistribusi normal. Sedangkan untuk uji multikolinearitas menunjukkan bahwa seluruh variabel independen memiliki nilai $\mathrm{VIF}<10$ dan nilai tolerance $>0,1$. Sehingga dapat disimpulkan bahwa model regresi tidak mengandung multikoninearitas.

Kemudian untuk uji heteroskedastisitas menunjukkan bahwa tidak ada satupun variabel independen yang signifikan secara statistik mempengaruhi variabel dependen. Hal ini terlihat dari probabilitas signifikannya $>0,05$, maka hal ini menunjukkan bahwa tidak terjadi heteroskedastisitas pada model. Dan untuk uji autokorelasi, dengan menggunakan uji Run Tets menunjukkan bahwa nilai probabilitas adalah sebesar 0.923 dan lebih besar dari 0.05, maka dapat disimpulkan bahwa model tidak terjadi autokorelasi.

\section{Uji Hipotesis Penelitian (Uji t)}

Analisis ini dilakukan untuk mengetahui seberapa jauh variabel-variabel independen berpengaruh secara signifikan terhadap variabel dependen. Berdasarkan hasil pengujian uji $t$ pada tabel 1 menunjukkan bahwa: Nilai $\mathrm{t}_{\text {hitung }}$ untuk variabel capital adequacy ratio (CAR) sebesar 2.641 $>1.98157$, dan nilai sig $0.010<5 \%$, sehingga $\mathrm{H}_{0}$ ditolak yang artinya bahwa capital adequacy ratio (CAR) berpengaruh signifikan terhadap business risk yang diukur dengan standar deviasi return on asset (SDROA). Nilai $\mathrm{t}_{\text {hitung }}$ untuk variabel non performing loan (NPL) 
sebesar $3.641>1.98157$, dan nilai sig $0.000<$ $5 \%$, sehingga $\mathrm{H}_{0}$ ditolak yang artinya bahwa non performing loan (NPL) berpengaruh signifikan terhadap business risk yang diukur dengan standar deviasi return on asset (SDROA).

Nilai $\mathrm{t}_{\text {hitung }}$ untuk variabel loan to deposit ratio (LDR) sebesar $0.686<1.98157$, dan nilai sig 0.494> $5 \%$, sehingga $\mathrm{H}_{0}$ diterima yang artinya bahwa loan to deposit ratio (LDR) tidak berpengaruh signifikan terhadap business risk yang diukur dengan standar deviasi return on asset (SDROA). Hasil $\mathrm{t}_{\text {hitung }}$ untuk variabel net interest margin (NIM) sebesar $3.809>1.98157$, dan nilai sig sebesar $0.000<5 \%$, sehingga $\mathrm{H}_{0}$ ditolak yang artinya bahwa net interest margin (NIM) berpengaruh terhadap business risk yang diukur dengan standar deviasi return on asset (SDROA). Hasil $\mathrm{t}_{\text {hitung }}$ untuk variabel size (ukuran perusahaan) sebesar $-0.493<1.98157$, dan nilai sig sebesar $0.623>5 \%$, sehingga $\mathrm{H}_{0}$ diterima yang artinya bahwa size (ukuran perusahaan) tidak berpengaruh terhadap business risk yang diukur dengan standar deviasi return on asset (SDROA).

\section{Pembahasan}

\section{Pengaruh capital adequacy ratio terhadap business risk.}

Berdasarkan parameter dari koefisien regresi dapat dijelaskan bahwa semakin tinggi capital adequacy ratio (CAR), maka semakin tinggi pula tingkat risiko bisnis bank. Hal ini dikarenakan bahwa rata-rata perusahaan perbankan dalam aspek keuangannya lebih ditekankan kepada aspek permodalan. Sehingga tingkat perputaran uangnya sangat rendah, hal ini akan mengakibatkan tingkat pengembalian laba juga semakin rendah. Sedangkan menurut Distinguin et.al (2011) rasio ekuitas terhadap total aset (EQTA) memiliki efek ambigu pada langkahlangkah pengambilan risiko perbankan. Besarnya CAR atau permodalan yang dimiliki oleh bank terbukti mampu menganggung besarnya risiko yang dihadapi oleh bank dan menjaga tingkat kepercayaan masyarakat.

\section{Pengaruh non performing loan terhadap business risk.}

Berdasarkan parameter dari koefisien regresi dapat dijelaskan bahwa semakin tinggi NPL, maka semakin tinggi pula tingkat risiko bisnis bank. Tingginya tingkat kredit macet yang ditunjukkan dengan tingginya NPL mengindikasikan rendahnya kemampuan debitur dalam membayar seluruh pinjaman atau kredit yang diberikan bank.

\section{Pengaruh loan to deposit ratio terhadap business Risk.}

Berdasarkan parameter dari koefisien regresi dapat dijelaskan bahwa semakin tinggi LDR, maka semakin tinggi tingkat risiko bisnis bank. Sebaliknya, semakin rendah LDR, maka akan semakin rendah risiko bisnis bank. Tingkat loan to deposit ratio (LDR) yang tinggi menunjukkan tingkat kredit yang diberikan tinggi, atau dengan kata lain bank meminjamkan seluruh dananya atau relatif tidak likuid karena jumlah dana yang diperlukan untuk membiayai kredit semakin besar.

\section{Pengaruh net interest margin terhadap business risk.}

Berdasarkan parameter dari koefisien regeresi dapat dijelaskan bahwa semakin tinggi net interest margin (NIM), maka semakin tinggi tingkat risiko bisnis bank. Sebaliknya, semakin rendah NIM, maka akan semakin rendah pula risiko bisnis bank. Besarnya pendapatan bunga atau net interest margin (NIM) yang dimiliki bank tidak terbukti mampu menurunkan tingkat risiko bisnis yang harus ditanggung oleh bank. Hal ini terjadi karena saat suku bunga berubah, pendapatan bunga dan biaya bunga bank akan berubah. 


\section{Pengaruh ukuran perusahaan terhadap business risk.}

Berdasarkan parameter dari koefisien regresi dapat dijelaskan bahwa semakin besar ukuran perusahaan (size) maka semakin rendah tingkat risiko bisnis bank. Sebaliknya, semakin rendah ukuran perusahan (size), maka akan semakin tinggi risiko bank. Tidak signifikannya variabel ukuran perusahaan (size) dalam mempengaruhi business risk pada perbankan yang go public mengindikasikan bahwa besar-kecilnya ukuran perusahaan belum tentu mempengruhi besarnya business risk. Bank dengan total aset yang besar memiliki kemampuan untuk diversifikasi sehingga bank memiliki pendapatan yang lebih stabil untuk mengurangi tingkat risiko.

\section{KESIMPULAN DAN SARAN}

Berdasarkan hasil analisis dan pengujian hipotesis yang telah dibahas di atas, maka dalam bagian ini akan disajikan kesimpulan atas hasil penelitian dan saran.

\section{Kesimpulan}

Berdasakan hasil pengujian hipotesis diperoleh capital adequacy ratio (CAR), non performing loan (NPL) dan net interest margin (NIM) berpengaruh positif dan signifikan terhadap business risk. Sedangkan loan to deposit ratio (LDR) mempunyai pengaruh positif dan tidak signifikan terhadap business risk dan size (ukuran perusahaan) berpengaruh negatif dan tidak signifikan terhadap business risk.

Beberapa keterbatasan dalam penelitian ini antara lain: (1) Variabel yang digunakan dalam penelitian hanya terbatas pada beberapa variabel kondisi keuangan. Hal ini menyebabkan penelitian tidak mampu mengukur secara komprehensif pengaruh kondisi keuangan terhadap business risk. (2) Jenis perusahaan yang digunakan sebagai sampel dalam penelitian ini hanya perusahaan perbankan yang go public saja, sehingga hasil penelitian tidak dapat digeneralisasi pada perusahaan perbankan yang non go public. (3) Periode penelitian ini cukup pendek yaitu hanya lima tahun (2008-2012), sehingga hasil yang diperoleh kemungkinan tidak konsisten dengan penelitian sebelumnya dan kemungkinan memperoleh hasil yang berbeda jika periode yang diteliti lebih diperpanjang.

\section{Saran}

Dengan adanya berbagai keterbatasanketerbatasan dalam penelitian ini, maka penulis memberikan saran sebagai berikut: (1) Dilihat dari nilai $\mathrm{R}^{2}$ yang relatif kecil, maka penelitian berikutnya diharapkan menambah variabel lain karena sangat dimungkinkan ada variabel lain yang tidak dimasukkan dalam penelitian ini yang mungkin memiliki pengaruh terhadap business risk seperti beban operasional pendapatan operasional (BOPO), pertumbuhan aset, dan lain sebagainya. (2) Bagi penelitian selanjutnya diharapkan dapat meneliti perusahaan perbankan yang non go public, sehingga hasil penelitian dapat digeneralisasikan. (3) Bagi penelitian selanjutnya diharapkan memperpanjang periode pengamatan, sehingga hasil penelitian akan lebih baik dan hasilnya konsisten dengan hasil penelitian sebelumnya.

\section{DAFTAR PUSTAKA}

Almalia, Luciana Spica dan Herdiningtyas, Winny. 2005. Analisa Rasio Camel Terhadap Prediksi Kondisi Bermasalah Pada Lembaga Perbankan Periode 20002002. Jurnal akuntansi dan keuangan. Vol 7, No. 2

Ariyanto, Taufik. 2011. Faktor Penentu Net Interest Margin Perbankan Indonesia. Finance And Banking Journal. Vol.13 No. 1 
Budiyanti dan Luluk M. Ifada. 2012. Karakteristik perusahaan dan kualitas implementasi corporate governance. EKOBIS Vol.14, No. 2

Daelawati,Mira., Rustam Hidayat., Dwiatmanto. 2013. Analisis Pengaruh ROA, CAR, NPL dan LDR Terhadap Perkembangan Kredit Perbankan (Studi Pada Sepuluh Bank Ternama Di Indonesia). administasibisnis. studentjournal.ub.ac. id /index.php/jab/article.

Defri. 2012. Pengaruh Capital Adequacy Ratio (CAR), Likuiditas dan Eficiensi Operasional Terhadap Profitabilitas Perusahaan Perbankan yang Terdaftar di BEI. Jurnal manajemen. Vol.1, No.1

Distinguin, Isabelle., Tchudjane Kouassi., Amine Tarazi. 2011. Deposit Insurance, Moral Hazard and Market Discipline: Evidence From Central and Eastern Europen Bank. Universite de Limoges-France.

Diantimala, Yossi. 2008. Pengaruh Akuntansi Konservatife, Ukuran Perusahaan Dan Default Risk Terhadap Koefisien Laba. Jurnal Telaah Dan Riset Akuntansi. V0.01, No.122

Godlewski, Christophe J. 2004. Bank Risk Taking in a Prospect Theory Framework Empirical Investigation in The Emerging Market's Case. Pole European de Gestion Et D'Economie, Universite Louis Pasteur

Hartono, Jogiyanto. 2010. Teori Portofolio dan Analisis Investasi. Yogyakarta: BPFE

Hanggraeni, Dewi. 2010. Pengelolaan Risiko Usaha. Jakarta: UI

Hendrayanti, Silvia dan Muharam, Harjum. 2013. Analisis Pengaruh Faktor Internal dan Eksternal Terhadap Profitabilitas Perbankan (Studi Pada Bank Umum Di Indonesia Periode Januari 2003 Februari 2012). Diponegoro Journal of management. Vol.2,No.3
Hutagalung,E. Novelina., Djumahir., Kusuma Ratnawati. 2013. Analisa Keuangan Terhadap Kinerja Bank Umum di indonesia. Jurnal Aplikasi Manajemen. Vol.2,No.1

Kasmir. 2009. Bank dan Lembaga Keuangan Lainnya. Jakarta: PT. Raja Grafindo Persada.

Kusumawati, Fariyana. 2009. Pengaruh Risiko Bank dan Profitabilitas Terhadap Harga Pasar Saham Pada Perusahaan Perbankan. Jurnal Akuntansi, Manajemen Bisnis dan sektor Publik (JAMBSP). Vol.6, No.1

Kwan, Simon. 2004. Testing The Strong From of Market Dicipline: The Effect of Public Market Signal on Bank Risk. Working Paper, Federal Reserve of San Franisco

Martono. 2004. Bank dan Lembaga Keuangan Lain. Yogyakarta: Ekonisia

Prasetyo, Ichsan Muhammad. 2013. Analisis Pengaruh Kecukupan Modal, Kredit Bermasalah, Likuiditas, dan Margin Bunga Bersih Terhadap Risiko Bisnis (Studi Pada Bank Umum Swasta Nasional Devisa. Jurnal Aplikasi Manajemen. Vol.2, No.2

Rahim, Rida dan Yuma, Irpa. 2008. Analisa efisiensi operasional terhadap profitabilitas pada bank umum syariah dan unit syariah (studi kasus BSM dan BNI syariah). Jurnal Bisnis dan Manajemen. Vol.04, No.4

Sembirnig, Sukmi Amelianty. 2012. Pengaruh Klasifikasi Industri Dan Ukuran Perusahaan Terhadap Risiko Bisnis Pada Perusahaan Manufaktur Yang Terdaftar Di Bursa Efek Indonesia. Jurnal manajemen. Vol.01, No.01

Soedarmono, Wahyoe., Fouad, Machrouh., Amine, Tarazi. 2010. Bank Competition, Risk and Capital Ratio: Evidence From Asia, Banking and Insurance. ejournal 
Sugiono. 2008. Metode Penelitian Bisnis. Veithzal, Rivai; Sofyan Basir; Sarwono Sudarto; Bandung: alfabeta.

Sunaryo, T. 2007. Manajemen Risiko Finansial. Jakarta: Salemba Empat

Taswan. 2010. Manajemen Perbankan: Konsep, Teknik dan Aplikasi. Yogyakarta: UPP STIM YKPN.

Taunay, E.G.Purwana. 2009. Analisis Pengaruh Capital Adequacy Ratio (CAR), Loan to Deposit Ratio (LDR), Size, BOPO Terhadap Profitabilitas (Studi Perbandingan Pada Bank Domestik dan Arifiandy P. Veithzal. 2013. Commercial Bank Management, Manajemen Perbankan Dari Teori Ke Praktik. Jakarta: PT. Raja Grafindo Persada

Veithzal, Rivai; Andria Permata Veithzal; Ferry N. Idrus. 2007. Bank and Financial Institution Management. Jakarta: PT. Raja Grafindo Persada

www.bi.go.id

www.idx.co.id

Jurnal.unimus.ac.id 